\title{
Effects of cotton stalk, maize stalk and almond bark on some soil microbial activities
}

\author{
Çiğdem Küçük*, Y.Tuba Tekgül \\ Harran University, Turkey \\ Science and Art Faculty, Department of Biology, Şanlıurfa \\ *Corresponding author's e-mail: cdmkucuk@yahoo.com, ckucuk@harran.edu.tr
}

Keywords: Organic residues, $\mathrm{CO}_{2}$ respiration, dehydrogenase and urease.

\begin{abstract}
With the increase of agricultural production, residues of crop are the main source of organic matter in the soil and they are alternatives to inorganic fertilizers. For this purpose, effects of organic residues (cotton stalk, maize stalk, almond bark) commonly grown in Turkey were investigated for some soil microbial activity in clay soil. In this study, incubation experiment was set up. Five doses $(0 \%, 2 \%, 4 \%, 6 \%$ and $8 \%)$ of organic residues (maize stalks, cotton stalks or almond bark) were applied to soil. Soil microbiological properties of soil samples such as $\mathrm{CO}_{2}$ respiration, dehydrogenase and urease activity were determined. According to the results obtained, maize stalk, cotton stalks and almond bark applications increased some soil microbiological activities, such as $\mathrm{CO}_{2}$ respiration, dehydrogenase and urease activities according to control soil. Maize stalk in comparison to other residues affects better on the biological properties of the soil. It is determined that enhancing effects of the added organic residues (maize stalk, cotton stalk, almond bark) into the soil were changed according to the type of organic residues, dosage and application terms.
\end{abstract}

\section{Introduction}

Turkey is one of the eight biggest countries which produce $80 \%$ of cotton in the world (www.tzob.org.tr). Maize is produced on approximately 550 thousand hectares with annual production of 3.5 million tons in Turkey (Özcan 2009). Turkey produces on about 13 thousand tons of almond (www.tzob.org.tr).

The majority of the plant residues is destroyed by burning (Ozores-Hampton et al. 2011). Burning of residues causes a direct loss of minerals in soils. The application of crop residues to soil stimulates soil microbial activity and growth (OzoresHampton et al. 2011). However, the effect of organic matter on soil properties depends on the type and rate of the added organic residues (Wolna-Maruwka et al. 2007). The use of plant residues has been associated with desirable soil physical, chemical and microbiological properties (Ferreras et al. 2007, Mattana et al. 2010, Okur et al. 2007, Treonis et al. 2010) and the effects of plant residues on plant growth and yield have been studied by Liang et al. (2005) and Poulsen et al. (2013). The use of these organic materials does not pose any risk (Ozores-Hampton et al. 2011).

Plant residues are an important source of nutrient and energy for microorganisms (Gouaerts et al. 2007). Apart from their direct nutrient contribution, plant residues effects soil properties (Okur et al. 2007, Stark et al. 2007), nutrients availability of soil and microbial populations (Chang et al. 2007, Hueso et al. 2012, Nicolardot et al. 2007). The effects of plant residues have been widely studied in recent years (Treonis et al. 2010, Wang et al. 2012).
Microorganisms play a significant role in decomposition of soil organic matter (Zhang et al. 2008). Different types of organic residues may affect soil microbiological properties (Bastian et al. 2009, Wolna-Maruwka et al. 2007). Many studies on soil biological properties as affected by organic amendments have been examined (Poulsen et al. 2013, Pratt 2008, Sawicka et al. 2004). The applications of plant residues and organic wastes significantly increased soil enzyme activity and microorganism population (Bastida et al. 2009, Wolna-Maruwka et al. 2007). In this study, maize stalks, cotton stalks and almond bark at different rations were applied to soil and the effects of these amendments on soil microbiological properties were studied.

\section{Materials and methods}

For the pot incubation experiment, maize stalks, cotton stalks and almond bark were chosen as organic residues that are widely grown in the region. The organic residues were oven-dried $\left(60^{\circ} \mathrm{C}\right)$ and ground in centrifuged mill $(200 \mu \mathrm{m}$ mesh) before adding to the soil. The soil was coarsely sieved $(6 \mathrm{~mm})$ and mixed throughly with the organic amendements. Five doses of organic residues $(0 \%, 2 \%, 4 \%, 6 \%$ and $8 \%)$ were applied to soil. Each pot contained $800 \mathrm{~g}$ of an individually prepared mixture. The main characteristics of organic residues are given in Table 1.

\section{Soil characteristics}

Soil characteristics were determined using Standard methods (Kaçar and Katkat 2007). Soil pH and conductivity were 
estimated using saturated soil solution (1/2.5; soil/water). Organic carbon was estimated by the method of Walkey (1947).

\section{Experimental set up}

Thorought the incubation period water losses exceeding $\sim 10 \%$ of the initial values were compensated by the addition of distilled water. Distilled water was added to each soil mixture to bring it to $60 \%$ of its water holding capacity. An unamended soil was used as control. The experiment was carried out in a growth chamber kept in darkness for 60 days at $28^{\circ} \mathrm{C}$. There were three replicates per treatment.

\section{Soil sampling}

Soil samples were taken after $0,7,15,30$ and 60 days of incubation for estimating microbial activity. The samples were collected from the pots and stored at $4{ }^{\circ} \mathrm{C}$ until analyzed.

\section{Analysis of soil biological activity Soil microbial respiration}

Microbial respiration $\left(\mathrm{CO}_{2}\right.$ production) was estimated using the method of Anderson and Domsch (1978). Total $\mathrm{CO}_{2}-\mathrm{C}$ collected in the $\mathrm{NaOH}$ flasks was determined by the addition of an excess of $1.5 \mathrm{M} \mathrm{BaCl}_{2}$ followed by titration with standardized $\mathrm{HCl}$ using a phenolphthalein indicator (Anderson 1982). Data are expressed as $\mathrm{mg} \mathrm{CO}_{2}-\mathrm{C} / \mathrm{g}$ dry sample. Soil respiration for all soil samples was measured at $0,7,15,30$ and 60 th days.

\section{Enzyme activities}

Dehydrogenase activity was determined according to Pepper et al. (1995). $30 \mathrm{mg}$ of glucose, $1 \mathrm{ml}$ of $3 \%$ TTC (2,3,5-triphenyltetrazoliumchlorid) solution and $2.5 \mathrm{ml}$ of distilled water were added to the $6 \mathrm{~g}$ soil samples and the content was mixed. The samples were incubated for $24 \mathrm{~h}$ at $37^{\circ} \mathrm{C}$. The formation of TPF (1,3,5-triphenylformazan) was determined spectrophotometrically at $485 \mathrm{~nm}$ and the results were expressed as $\mu \mathrm{g} \mathrm{TPF} / \mathrm{g}$ dry sample. Three replicates of each sample were tested.

Urease activity was measured according to Hoffmann and Teicher (1961). $250 \mu \mathrm{l}$ of toluene, $750 \mu \mathrm{l}$ of citrate buffer ( $\mathrm{pH}$ 6.7 ) and $1 \mathrm{ml}$ of $10 \%$ urea substrate solution were added to the $1 \mathrm{~g}$ sample and the samples were incubated for $3 \mathrm{~h}$ at $37^{\circ} \mathrm{C}$. Following filtration through whatman No. 42 filter papers and sodium phenolate and sodium hypochloride were added. The released ammonium was determined spectrophotometrically at $578 \mathrm{~nm}$. Three replicates of each sample were tested. The control sample without urea was prepared. Results were expressed as $\mu \mathrm{g} \mathrm{N} / \mathrm{g}$ dry sample.

\section{Statistical analyses}

All statistical analyses were performed using JUMP 10 packet program. Analysis of variance (ANOVA) and least significant difference (LSD) were employed to determine differences among treatments.

\section{Results and Discussion}

Physical and chemical properties of soil are shown in Table 2. As seen from this table, the soil has clay texture (sand 19.28\%, clay $60.72 \%$ and silt $20 \%$ ), with $\mathrm{pH}$ of $8.14,0.97 \mathrm{dS} / \mathrm{m}$ electrical conductivity (EC), $1.73 \%$ organic matter, $23.5 \% \mathrm{CaCO}_{3}$ content, $120.9 \mathrm{~kg} /$ da total $\mathrm{K}, 4.94 \mathrm{~kg} / \mathrm{da}$ total $\mathrm{P}$ and $0.05 \%$ total N. In this study, organic residues such as corn stalks, cotton stalks and almond bark have higher organic matter and $\mathrm{N}$ contents. Figure 1 shows the effect of the soil treatments on the soil respiration. Compared with the control, soil respiration was higher in all residues of treated soils $(\mathrm{p}<0.01)$ (Figure 1). Soil respiration was stimulated by organic residues during the incubation period (Figure 1). Soil respiration was significantly higher in $8 \%$ maize stalk soil $(\mathrm{p}<0.01)$ than in the control and all other treatment soil (Figure 1). These situations might be

Table 1. Composition of organic residues

\begin{tabular}{|l|c|c|c|}
\hline \multirow{2}{*}{ Chemical analysis } & \multicolumn{3}{|c|}{ Organic residues } \\
\cline { 2 - 4 } & Maize stalks & Cotton stalks & Almond bark \\
\hline $\mathrm{pH}$ & 5.61 & 5.85 & 5.29 \\
\hline $\mathrm{EC}(\mathrm{ds} / \mathrm{m})$ & 4.33 & 4.09 & 8.89 \\
\hline Organic matter $(\%)$ & 95 & 91 & 91 \\
\hline Organic C (\%) & 55 & 53 & 53 \\
\hline $\mathrm{N}(\%)$ & 0.96 & 1.00 & 0.92 \\
\hline $\mathrm{C} / \mathrm{N}$ & 53 & 52 & 56 \\
\hline $\mathrm{Ca}(\mathrm{ppm})$ & 3238 & 7718 & 5972 \\
\hline $\mathrm{Cu}(\mathrm{ppm})$ & 6.521 & 9.512 & 19.56 \\
\hline Fe $(\mathrm{ppm})$ & 75.34 & 69.89 & 333.2 \\
\hline $\mathrm{K}(\mathrm{ppm})$ & 12860 & 3278 & 15480 \\
\hline $\mathrm{Mg}(\mathrm{ppm})$ & 1269 & 1595 & 1303 \\
\hline $\mathrm{Mn}(\mathrm{ppm})$ & 32.85 & 10.86 & 17.02 \\
\hline $\mathrm{Na}(\mathrm{ppm})$ & 142.9 & 177.1 & 169.6 \\
\hline $\mathrm{P}(\mathrm{ppm})$ & 640.3 & 828.8 & 805.8 \\
\hline $\mathrm{Zn}(\mathrm{ppm})$ & 28.43 & 9.04 & 7.30 \\
\hline
\end{tabular}


related to organic matter contents of residues, which contains different amounts of organic matter and $\mathrm{N}$ (Table 1). The high organic matter contents of tested residues could increase respiration of the soils. Chang et al. (2007) and Pratt (2008) also indicated that organic treatments influenced microbial activity. This phenomenon may contribute to the increased soil respiration (Liang et al. 2005).

When highest doses of organic residues were applied to the soil, soil respiration increased progressively during the incubation period. Also, the lowest soil respiration value was measured in the control soil during incubation period (Fig. 1). At the end of the incubation, the highest increases were provided by maize stalks, almond bark and cotton stalks respectively, compared to the control. Similar results were reported by Liang et al. (2005) and Ferreras et al. (2007). However, Chang et al. (2007) and Ferreras et al. (2007) reported a strong stimulation of the rate of mineralization of organic carbon following the introduction of organic residues into experimental soils. On the other hand, Mattana (2010) maintains that soil respiration values were dependent on the $\mathrm{C} / \mathrm{N}$ ratio. A higher rate of $\mathrm{CO}_{2}$ production in the soil was recorded with increasing residue application rate (Fig. 1). The increase in respiration values could result from the soluble $\mathrm{C}$ derived from the application of plant residues. The soil respiration is a commonly used parameter reflecting microbial activity (Ferreras et al. 2007, Okur et al. 2007). According to the researchers, the increase may be attributed to humic compounds in residues (Chang et al. 2007, Ferreras et al. 2007). Soil microbial respiration was increased in pots treated with maize stalk and cotton stalk according to the control (118\% and $89 \%$, respectively). However, organic matter degrading microorganisms and other ingredients of the soil may be responsible for increased respiration. As indicated by many studies, the changes in microbial respiration in soil treated with residues have been related closely to the dosages of residues used (Ferreras et al. 2007). The effects of different application rates of maize stalks, cotton stalks and almond barks on dehydrogenase activity are shown in Figure 2. As shown in Figure 2, the dehydrogenase activities in soil treated with residues were significantly higher than values in the control. The dehydrogenase activity in soils treated with organic residues was higher than that of the control. The lowest dehydrogenase activity was measured in the control soil (Figure 2).

The highest dehydrogenase activity values were measured in $8 \%$ cotton stalk application and $8 \%$ almond bark application at 7 th day of incubation. Dehydrogenase activity in soil; reflects the total range of oxidative activity of soil microflora and it is used as an indicator of microbial activity (Markowicz et al. 2016, Ozores-Hampton et al. 2011, Stark et al. 2007, Tejada et al., 2006). Ozores-Hampton et al. (2011) reported that the application of agricultural residues caused a significant increase in dehydrogenase activity. The enzyme activity in organic residue treatments increased on average 2-7 times compared with the control soil (Benitez et al. 2004, Mattana et al. 2010; Szwed and Bohacz 2014). These results were similar to our finding that dehydrogenase activity showed increased activity in respon se to the applications according to control. The activity of urease is widely used in the evaluation of changes in soil quality for soil management (Liang et al. 2005). In this study, urease activity was increased with the application of residues, although nitrogen fertilizer was not applied. The
Table 2. Physical and chemical properties of the soil used in the pot experiment

\begin{tabular}{lc}
\hline Soil properties & Values \\
\hline Sand $(\%)$ & 19.28 \\
Silt $(\%)$ & 60.72 \\
Clay $(\%)$ & 20.0 \\
Texture class & clay \\
$\mathrm{pH}\left(1: 2.5 \mathrm{w} / \mathrm{v} \mathrm{H}_{2} \mathrm{O}\right)$ & 8.14 \\
Organic matter $(\%)$ & 1.73 \\
Available $\mathrm{P}\left(\mathrm{kg} \mathrm{da}^{-1}\right)$ & 4.94 \\
Exchangeable K $\left(\mathrm{kg} \mathrm{da}^{-1}\right)$ & 120.9 \\
Available N $(\%)$ & 0.05 \\
${\mathrm{EC}\left(\mathrm{dS} \mathrm{m}^{-1}\right)}^{\mathrm{CaCO}_{3}(\%)}$ & 0.97 \\
\hline
\end{tabular}
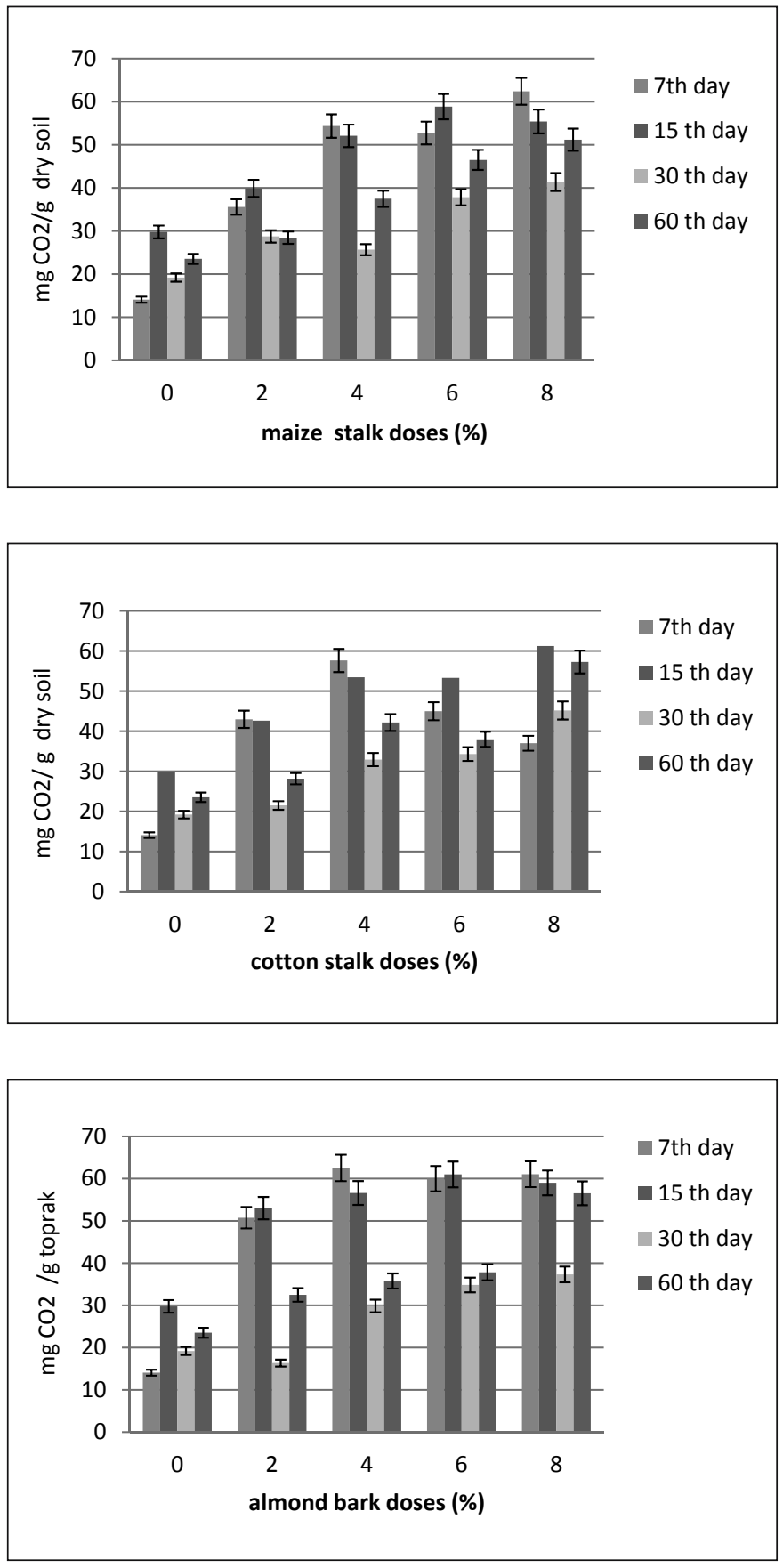

Fig. 1. Effects on soil respiration of organic residues $(p<0.01)$ 
activities of urease that catalyze the hydrolysis of urea and urease activity in soils are widely used in the evaluation of changes in soil quality (Benitez et al. 2004), increased with the application of plant residues (Fig. 3).

The lowest urease activity was observed in the control pots and the highest was observed in plant residues-treated applications. Urease activity showed increased activity in response to the application of $2 \%$ maize stalk and $4 \%$ cotton stalk at 30 th day of incubation, and the application of $6 \%$ almond bark at 60 day of incubation (Fig. 3) as compared to the control. A significant $(\mathrm{p}<0.05)$ increase in urease activity values was observed in all residue-treated soil, as compared the control soil.

Similar results have been reported by Hueso et al. (2012), Franco-Otero et al. (2012) and Okur et al. (2007) who worked with different plant residues. During the experiment, the soil respiration, dehydrogenase and urease activity values were significantly affected by organic residues, rates of organic residues and application time (Table 3).
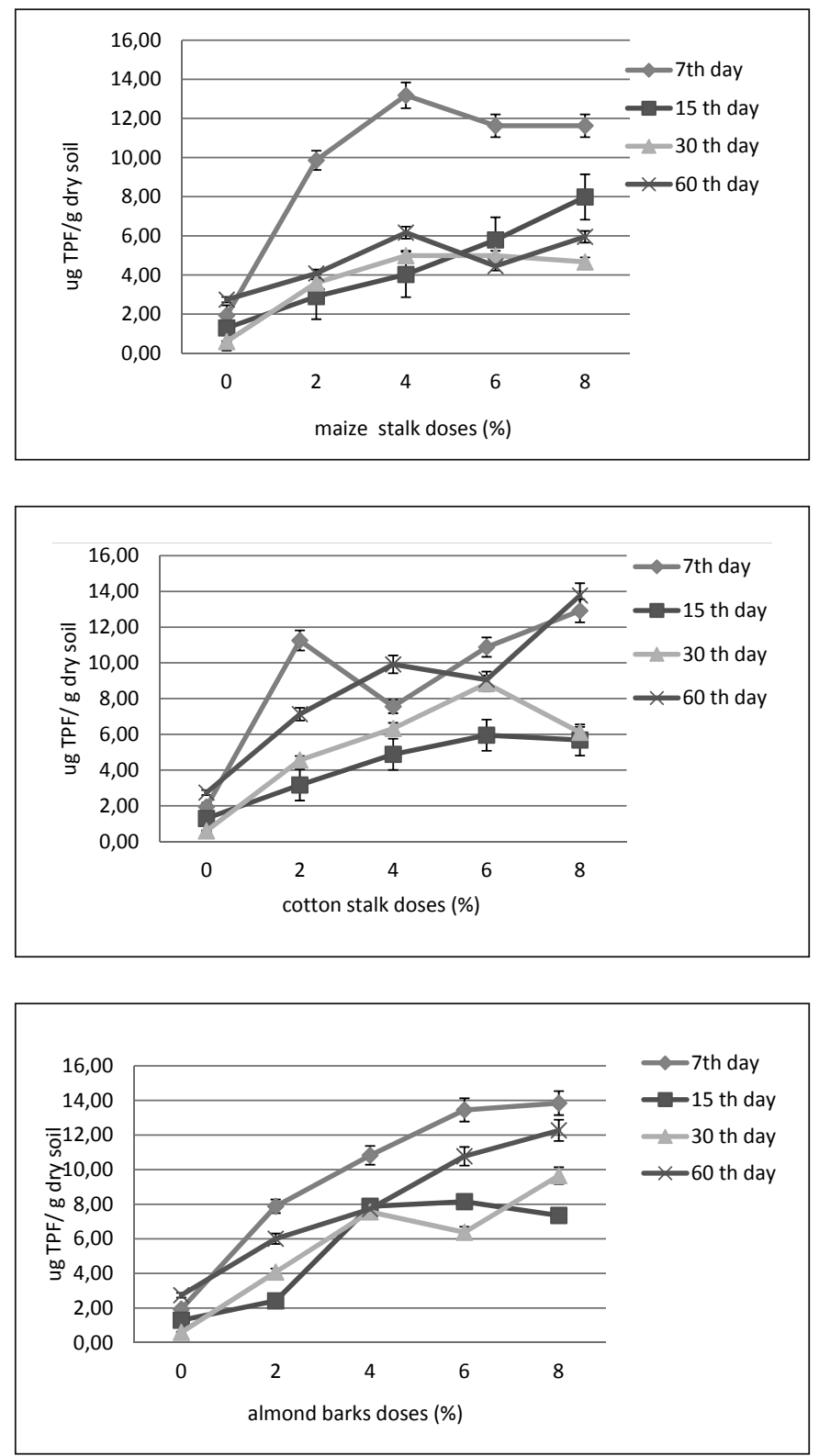

Fig. 2. Effects on soil dehydrogenase activity of organic residues $(p<0.01)$
This may be mainly due to the nutrient inputs for microbial development derived from the organic treatments. Differences in dehydrogenase and urease activities under different organic residues-treatments and doses may be ascribed to differences in the decomposition rates of organic wastes or to different effects of various doses on the soil microbial properties as reported by Wolna-Maruwka et al. (2007), Sawicka et al. (2004).

\section{Conclusion}

In this study, soil respiration, urease and dehydrogenase activities were higher in pots treated with plant residues. These effects of the organic residues have been demonstrated by different authors (Ozores-Hampton et al. 2011, Poulsen et al. 2013, Szwed and Bohacz 2014). Although there was a significant difference in soil microbiological properties tested in this study, the respiration ratio, dehydrogenase and urease enzyme activities varied according to the type, application rate
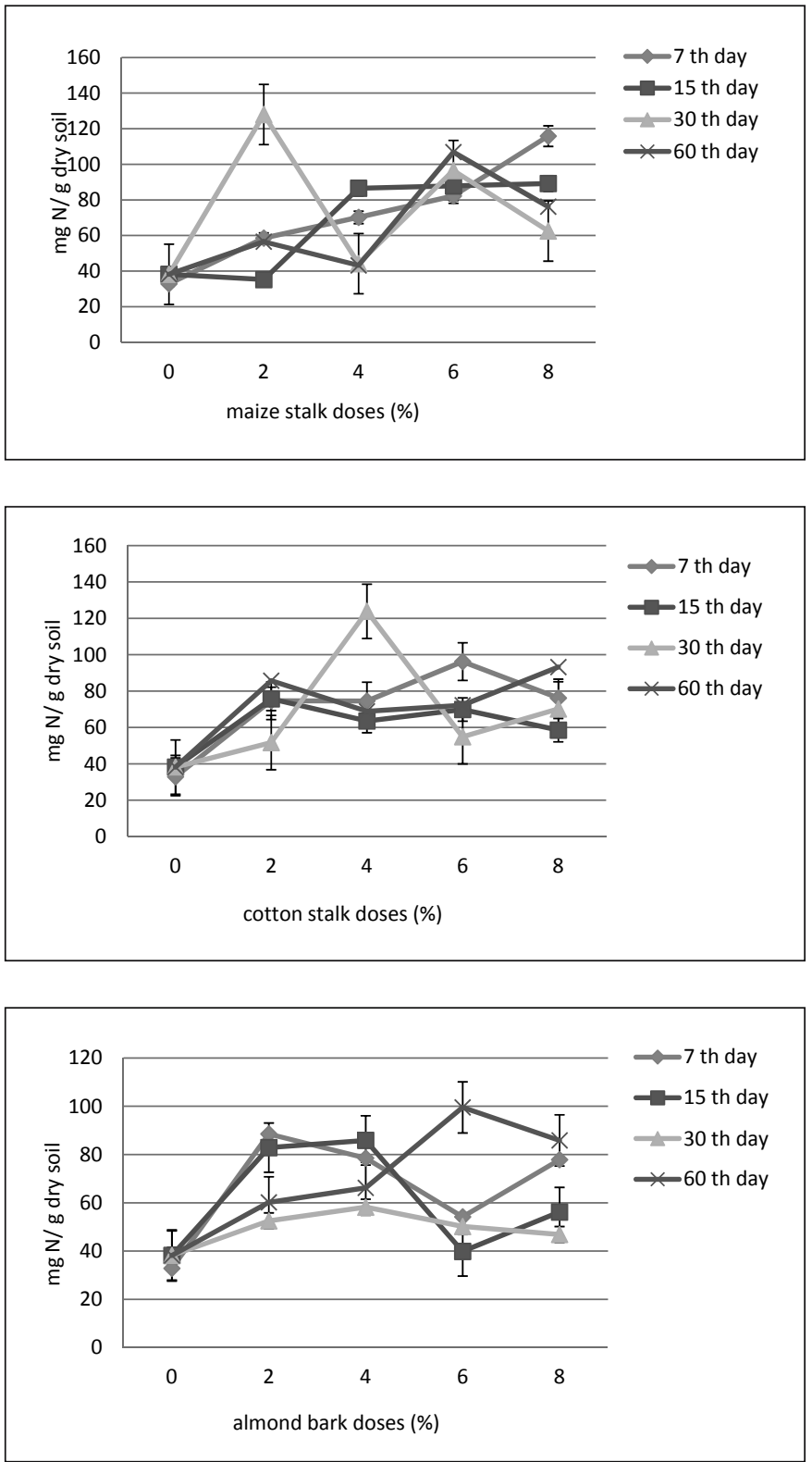

Fig. 3. Effects on soil urease activity of organic residues $(\mathrm{p}<0.05)$ 
Table 3. Effects of maize stalk, cotton stalk and almond bark on respiration ( $\mathrm{mg} \mathrm{CO}_{2} / \mathrm{g}$ dry soil), dehydrogenase activity ( $\mu \mathrm{g}$ TPF/g dry soil) and urease activity(mg N/g dry soil)

\begin{tabular}{|c|c|c|c|c|}
\hline \multicolumn{2}{|c|}{ Treatments } & Soil respiration & Dehydrogenase & Urease \\
\hline \multirow{3}{*}{ Organic residues } & maize stalk & $40.27 a$ & $5.62 b$ & $71.03 a$ \\
\hline & cotton stalk & $35.60 \mathrm{~b}$ & $6.79 a$ & $75.15 a$ \\
\hline & almond bark & $34.83 b$ & $7.13 a$ & $62.53 a$ \\
\hline \multicolumn{2}{|c|}{ LSD } & $(1 \%): 1.80$ & $(1 \%): 0.63$ & ns \\
\hline \multirow{5}{*}{ Application time } & 7 & $34.87 \mathrm{c}$ & $9.40 \mathrm{a}$ & $68.75 a$ \\
\hline & 15 & $45.73 a$ & $4.66 c$ & $63.85 a$ \\
\hline & 30 & $29.51 d$ & $4.96 c$ & $63.02 a$ \\
\hline & 60 & $37.50 b$ & $7.04 b$ & 68.68 \\
\hline & LSD & $(1 \%): 2.08$ & $(1 \%): 0.78$ & ns \\
\hline \multirow{6}{*}{ Doses } & 0 & $22.08 d$ & $1.64 d$ & $37.61 \mathrm{~b}$ \\
\hline & 2 & $35.49 c$ & $5.58 c$ & $84.48 a$ \\
\hline & 4 & $45.19 a$ & $7.58 \mathrm{~b}$ & $71.98 a$ \\
\hline & 6 & $38.17 b$ & $8.46 a b$ & $73.07 a$ \\
\hline & 8 & $43.59 a$ & $9.31 \mathrm{a}$ & $75.73 a$ \\
\hline & LSD & $(1 \%): 0.13$ & $(1 \%): 0.19$ & $(1 \%): 0.23$ \\
\hline
\end{tabular}

ns: not significant

and time of plant residues used. The use of plant residues can lead to an increase in the quality of the soil.

\section{Acknowledgement}

We would like to thank the Harran University for the financial support.

\section{References}

Anderson, J.P.E. \& Domsch, K.H. (1978). A physiological method for the quantitative measurement of microbial biomass in soils, Soil Biology and Biochemistry, 10, pp. 215-221.

Anderson, J.P.E. (1982). Soil respiration. In: methods of soil analysis, part 2, chemical and microbiological properties (Ed. AL. Page), ASA-SSSA, Madison, Winsconsin, pp. 831-871.

Bastida, F., Kandeler, E., Moreno, J.L., Ros, M., Garcia, C. \& Hernandez, T. (2008). Application of fresh and composted organic wastes modifies structure, size and activity of soil microbial community under semiarid climate, Applied Soil Ecology, 40, pp. 318-329.

Bastian, F., Bouziri, L., Nicolardot, B. \& Lionel, R. (2009). Impact of wheat straw decomposition on successional patterns of soil microbial community structure, Soil Biology and Biochemistry, 41, pp. 262-275.

Benitez, E., Melgar, R. \& Nogales, R. (2004). Estimating soil resilience to a toxic organic waste by measuring enzyme activities, Soil Biology and Biochemistry, 36, pp. 1615-1623.

Chang, E., Chung, R. \& Tsai, Y. (2007). Effect of different application rates of organic fertilizer on soil enzyme activity and microbial population, Soil Science and Plant Nutrition, 53, pp. 132-140.

Ferreras, L., Gomez, G., Toresani, S., Firpo, I. \& Rotondo, R. (2007). Effect of organic amendments on some physical, chemical and biological properties in a horticultural soil, Bioresource Technology, 97, pp. 635-640.

Franco-Otero, V.G., Soler-Rovira, P., Hernández, D., López-Desá, E.G. \& Plaza, G. (2012). Short-term effects of organic municipal wastes on wheat yield, microbial biomass, microbial activity and chemical properties of soil, Biology Fertility of Soils, 48, pp. 205-216.

Gouaerts, B., Mezzalama, M., Unno, Y., Sayre, K.D., Luna-Guido, M., Vanherck, K., Dendoouen, L. \& Deckers, J. (2007). Influence of tillage, residue management, and crop rotation on soil microbial biomass and catabolic diversity, Applied Soil Ecology, 37, pp. $18-30$.

Hoffmann, G.G. \& Teicher, K. (1961). A colorimetric method for the determination of urease activity in soils, Zeitschrift für Pflanzenernahrung und Bodenkunde (Journal of Plant Nutrition and soil Science), Bodenk, 91, pp. 55-63.

Hueso, S., Garcia, C. \& Hernandez, T. (2012). Severe drought conditions modify the microbial community structure, size and activity in amended and unamended soils, Soil Biology and Biochemistry, 50, pp. 167-173.

Kacar, B. \& Katkat, V. (2007). Plant nutrition, Nobel Publish. ISBN: 978-975-591-834-1. pp. 559.

Liang, Y., Si, J., Nikolic, M., Peng, Y., Chen, W. \& Jiang, Y. (2005). Organic anure Stimulates Biological Activity and Barley Growth in Soil Subject to Secondary Salinization, Soil Biology and Biochemistry, 37, pp. 1185-1195.

Markowicz, A., Płaza, G. \& Piotrowska-Seget, Z. (2016). Activity and functional diversity of microbial communities in long-term hydrocarbon and heavy metal contaminated soils, Archives of Environmental Protection, 42, pp. 3-11.

Mattana, S., Ortiz, O. \& Alcaniz, J.M. (2010). Substrate-induced respiration of a sandy soil treated with different types of organic waste, Communications in Soil Science and Plant Analysis, 41, pp. 408-423.

Nicolardot, B., Bouziri, L., Bastian, F. \& Ranjard, L. (2007). A microcosm experiment to evaluate the influence of location and quality of plant residues on residue decomposition and genetic structure of soil microbial communities, Soil Biology and Biochemistry, 39, pp. 1631-1644.

Okur, N., Kayıkçığlu, H.H., Okur, B. \& Delibacak, S. (2008). Organic amendment based on tobacco waste compost and farmyard manure: Influence on soil biological properties and butter-head 
lettuce (Lactuca sativa L. var. capitata L.) yield, Turkish Journal of Agriculture and Forestry, 32(2), pp. 91-99.

Ozores-Hampton, M., Stansly, P.A. \& Salame, T.P. (2011). Soil chemical, physical, and biological properties of a sandy soil subjected to long-term organic amendments, Journal of Sustainable Agriculture, 35(3), pp. 243-259.

Özcan, S. 2009. Corn, Indispensable Crop of the Modern World: Contribution of genetically modified (Transgenic) corn on agricultural production, Türk Bilimsel Derlemeler Dergisi, 2, pp. 01-34

Pepper, I.L., Gerba, C.P. \& Brendecke, J.W. (1995). Brendecke: Environmental Microbiology, A Laboratory Manual. Academic Press, New York 1995.

Poulsen, H.P.B., Magid, J., Luxhoi, J. \& De Neergaard, A. (2013). Effects of fertilization with urban and agricultural organic wastes in a field trial- waste imprint on soil microbial activity, Soil Biology and Biochemistry, 57, pp. 794-802.

Pratt, R.G. (2008). Fungal population levels in soils of commercial swine waste disposal sites and relationship to soil nutrient concentrations, Applied Soil Ecology, 38, pp. 223-229.

Sawicka, A., Czekala, J. \& Wolna, A. (2004). Dynamics of the development of microorganisms in soils fertilised with sewage sludge and tobacco dust, Proceedings of the 10 th International Conference of the RAMIRAN Network. Slovak Republic, May 14-18 2002, pp. 201.

Szwed, A. \& Bohacz, J. (2014). Enzymatic activity and certain chemical properties of grey-brown podzolic soil (Haplic luvisol) amended with compost of tobacco wastes, Archives of Environmental Protection, 40, pp. 61-73.
Stark, C., Condron, L.M., Stewart, A., Di, H.J. \& O'Callaghan, M. (2007). Influence of organic and mineral amendments on microbial soil properties and processes, Applied Soil Ecology, 35, pp. 79-93.

Tejada, M., García, C., González, J.L. \& Hernández, M.T. (2006). Use of organic amendment as a strategy for saline soil remediation: influence on the physical, chemical and biological properties of soil, Soil Biology and Biochemistry, 38, pp. 1413-1421.

Treonis, A.M., Austin, E.E., Buyer, J.S., Maul, J.E., Spicer, L. \& Zasada, I.A. (2010). Effects of organic amendment and tillage on soil microorganisms and microfauna, Applied Soil Ecology, 46, pp. 103-110.

Walkey, A. (1964). A critical examination of a rapid method for determining organic carbon in soils effect of variations in digestion conditions and of inorganic soil constituents, Soil Science, 63, pp. 251-263.

Wang, J.J., Li, X.Y., Zhu, A.N., Zhang, X.K., Zhang, H.W. \& Liang, W.J. (2012). Effects of tillage and residue management on soil microbial communities in North China, Plant Soil Environment, 58, pp. $28-33$.

Wolna-Maruwka, A., Sawicka, A. \& Kayzer, D. (2007). Size of selected groups of microorganisms and soil respiration activity fertilized by municipal sewage sludge, Polish Journal of Environmental Studies, 16, pp. 129-138.

Zhang. Q.Z., Yang, Z.L. \& Wu, W.L. (2008). Role of crop residue management in sustainable agricultural development in the North China Plain, Journal of Sustainable Agriculture, 32, pp. 137-148.

www.tzob.org.tr $(01.12 .2010)$ 